\title{
Kansas kicks evolution out the classroom
}

[SAN DIEGO] US scientists are being urged to become more involved in debates over the teaching of evolution following last week's decision by the Kansas Board of Education to halt the study of evolutionary biology in public schools.

Siding with creationists, the publicly elected Kansas board voted to approve standards for kindergarten through twelfthgrade students that eliminate the required teaching of evolution, cosmology and some sciences related to the Earth's origin. Local school districts will use these standards to set their curriculums.

"Many scientists were dismayed when the Kansas board voted to eliminate the theory of evolution from the state's science curriculum, and some will undoubtedly express shock and disapproval," says Fred Spilhaus, executive director of the 35,000-member American Geophysical Union (AGU). "What is needed from scientists now is not expressions of outrage, but active participation in state and local decision making."

But, while the AGU issued a rallying call, some major US organizations - including the American Association for the Advancement of Science and the National Academy of Sciences - declined to comment on the decision. The organizations have longstanding policies supporting the teaching of evolutionarybiology.

In Kansas, there was shock and embarrassment. Governor Bill Graves, a Republican from a rural city, issued a statement saying: "This is a tragic, terrible, embarrassing solution to a problem that didn't exist."

The presidents of the six public universities in Kansas have said in a public statement that the changed standards "will be detrimental to the future of science education in Kansas" and "will set Kansas back a century," giving "hard-to-find science teachers no choice but to pursue other career fields".

There are concerns that students will perform poorly in college entrance examinations, that universities will find it harder to attract quality science professors, and that businesses may have difficulty recruiting from other regions.

Steven Case, an experienced Kansas educator and head of Citizens for Science, a group that opposed the board's decision, said he feared the decision will have longterm negative consequences. Not teaching evolutionary biology, Case said, would impair the learning process, as studies show that knowledge is most likely to be retained "when the learner knows and understands underlying principles that can be applied to problems in new contexts".

The board "not only ignores good science, it also ignores what we know about learning," said Case. But Linda Holloway, president of the Kansas Board of Education, who voted in the six to four majority on 11 August, said previous state standards placed too "heavy an emphasis on evolution".

A former teacher of disabled children, Holloway from Shawnee, Kansas, says she “doesn't see evidence" for 'macroevolution' - the evolution of higher species from lower forms of life. But she says that she believes in 'microevolution' - the view that species can evolve within their group.

Critics of the board's new standards, says Holloway, "are making the assumption that local people don't have the capability to

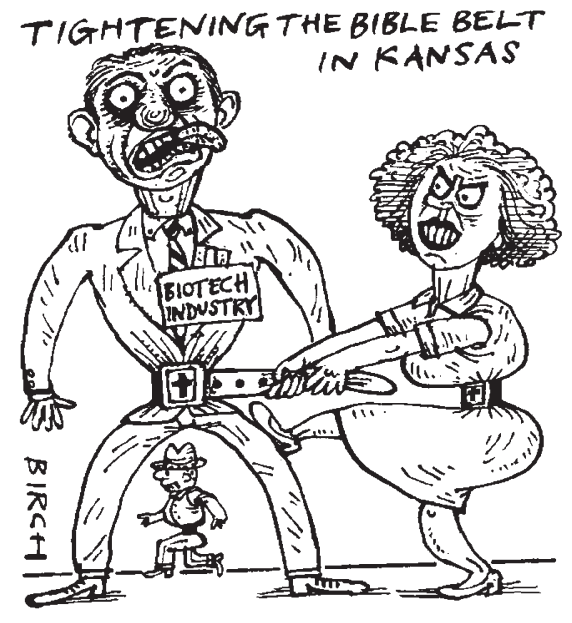

decide what good education is on their own".

The new standards appear to be part of a campaign by creationists to further their cause through the political process. A Missouri-based group called the Creation Science Association of Mid-America, which opposes teaching evolution in schools, was closely involved in the Kansas effort.

Having put their imprint on state regulations in Kansas, the creationists are expected to move to the school-district level, and try to alter the school science curriculum.

Citizens for Science have said that the approved standards "are illegal to teach in public schools" and are the result of "a fringe group" following "a political strategy".

It remains unclear whether the battle will end up in court, as has occurred in other states. Kansas' governor wants a state constitutional amendment to abolish the board. But previous statewide votes to eliminate the board have failed. RexDalton

\section{Cray sale threatens to send researchers shopping elsewhere}

[SAN DIEGO] The parent corporation of Cray supercomputers announced plans last week to sell the computer manufacturer, prompting new concern among scientific users already frustrated by slow part availability and the failure to develop competitive products.

The sale is part of a reorganization by Silicon Graphics Inc., the Mountain View, California, company that bought Cray about three years ago. Silicon Graphics also plans to lay off up to 1,500 employees, and concentrate on developing mid-sized, highperformance servers for the Internet.

The Cray supercomputers and some associated technologies will form a new business unit under the direction of Steve Oberlin, a respected supercomputer specialist. Silicon Graphics says that it then plans to sell all or part of that unit.

"We have decided that pursuing these

NATURE | VOL 400| 19 AUGUST 1999 |www.nature.com agendas separately but in coordination creates the best opportunity for the success of both businesses," says Rick Belluzzo, Silicon Graphics' chairman and chief executive.

But the news met with scepticism and concern among some Cray users, who have endured what they call years of marginal service. "The sun is setting on Cray," says one. "And it is sad." Some clients are already switching to other brands of computer.

The Cray vector supercomputers, made in Eagan, Minnesota, and Chippewa Falls, Wisconsin, were developed by the late Seymour Cray. Researchers value them for their ability to produce data rapidly from each cycle of the computer's internal clock. They are good for climate and weather forecasting, and have long been used by the US National Weather Service in Maryland.

But supercomputer specialists say that, in recent years, the Cray has fallen behind its competitors. Many of Cray's best computer scientists have left the company, moving to competitors such as IBM, which now is taking Cray's clients.

The National Weather Service is replacing its Cray C90 with an IBM SPRS/6000. "The IBM beat out Cray on performance for the price," said Carl Staton, director of central operations for the Weather Service. And the San Diego Supercomputer Center at the University of California at San Diego has bought an IBM Teraflops machine to augment its Crays.

Privately, one computer scientist said that purchasers of high-end equipment became frustrated with Cray's constantly changing strategic direction under Silicon Graphics. "They didn't have good direction," says the scientist. "Their strategic plan was different every six months.”

R.D. 